\title{
ASPEK HUKUM WAKAF DALAM KAJIAN HADIS AHKAM (Melacak Akar Sejarah Hukum Wakai Dan Penerapannya di Indonesia)
}

\author{
Muhazir \\ Fakultas Syariah IAIN Langsa, Aceh \\ e-mail: muhazir@iainlangsa.ac.id
}

\begin{abstract}
The hadith on Waqf only describes waqf for immovable objects and it is in contrast to the current context in Indonesia which wants to develop a broader concept of waqf not just for immovable objects as described in Law Number 41 of 2004 on Waqf. The paradigm between the hadith text and its application in Indonesia causes a different understanding, so it is necessary to reunderstand the hadith text in its current context. The purpose of this article is to look at legal hadiths about waqf by tracing the history of waqf and its application in Indonesia. The results of the research show that the hadith narrated by Bukhâri about waqf contained in the Syurûth chapter Number 19 is the legal basis for waqf used by the Muslim clergy. This hadith only describes the status of waqf objects, while in Indonesia itself the Waqf Law leads to productive waqf and cash.
\end{abstract}

Keyword: Hadith, Waqf, Waqf Regulations

\section{P e n d a h u lu a n}

Wakaf merupakan bagian terpenting dalam kajian filantropi karna mampu memberikan pengaruh terhadap perkembangan ekonomi. Masyarakat muslim dunia saat ini serius dalam upaya pengembangan ekonomi Islam dan berusaha mengkaji teori ekonomi yang memiliki peranan besar dalam membentuk ekonomi yang sehat dan lebih cepat berkembang seperti halnya wakaf. Wakaf dianggap cepat dalam pertumbuhan ekonomi untuk mewujudkan ekonomi berbasis kerakyatan dengan menerapkan konsep ta'āwun. Di samping itu, antusias masyarakat muslim dalam beramal dapat mempercepat meningkatnya aset wakaf sehingga perlu untuk dikembangkan.

Akhir-akhir ini issu tentang wakaf hangat diperbincangkan diberbagai negara. Banyak negara-negara timur tengah berhasil meningkatkan tarap ekonomi dengan program wakaf, seperti Saudi Arabia, Tunisia, ${ }^{1}$ Mesir, Malaysia, Banglades, Qatar, Kuwait bahkan Singapura telah menerapkan

${ }^{1}$ Budi Juliandi, "Wakaf Dan Politik Di Tunisia," AHKAM : Jurnal Ilmu Syariah 15, no. 2 (July 20, 2015): 137-144, https://doi.org/10.15408/ajis.v15i2.2857. 
pengelolaan wakaf, ${ }^{2}$ dikarenakan wakaf memiliki damapak yang signifikan terhadap kesejahteraan umat. Bahkan, dengan seriusnya negara-negara tersebut mendirikan lembaga wakaf khusus untuk menangani harta wakaf.

Wakaf salah satu bentuk perekonomian yang memiliki konsep keseimbangan baik keseimbangan dalam kehidupan dunia maupun akhirat. Konsep tersebut merpakan tujuan wakaf yang merupakan bagian dari sarana ibadah dan suatu bentuk pengabdian kepada Allah SWT dan juga sebagai bentuk komunikasi serta keseimbangan spiritual manusia dengan penciptanya. keseimbangan pada gilirannya akan menghadirkan keserasian diri dengan alam dan ilahi yang memiliki tujuan mewujudkan menciptakan harmonisasi dalam hidup. Oleh karena itu, kebanyakan para ulama memberi definisi bahwa wakaf merupakan penahanan terhadap harta benda yang diambil manfaatnya dan pahala bagi yang mewakafkan hartanya di jalan Allah.

Wakaf merupakan suatu bentuk penahanan harta seseorang yang bertujuan untuk dimanfaatkan hasilnya pada jalan yang telah ditentukan dalam Islam, sebagaimana yang dijelaskan oleh Imam Taqiyuddin Abi Bakr bahwa wakaf; ${ }^{3}$

$$
\text { حبس مال تصرف منافعه في البر تقربا الي الله }
$$

Maksud dari pernyataan Taqiyuddin Abi Bakr bahwa wakaf merupakan menahan harta benda yang difungsikan manfaatnya untuk kepentingan sosial baik itu bersifat individu maupun kelompok. Pemahaman ini sama halnya dengan apa yang diutarakan oleh Mudnzir Qahar, Alminawi dan Ibnu Arafah Al-Maliki. Harta wakaf adalah kepunyaan Allah dan bersifat kekal sehingga tidak dapat diambil atau dihilangkan. Harta wakaf tersebut ditahan tidak diperbolehkan untuk dipindahkan, wakaf tidak dapat diakhiri, karena ketika terjadi akad wakaf maka menjadi milik Allah, karena harta yang dijadikan wakaf tersebut tidak habis dipakai, dengan artian bahwa manfaat harta dapat digunakan dan wujud benda wakaf tidak dapat berubah.

Konsep wakaf yang terdapat dalam Al-Quran memang tidak dijelaskan secara dhahir an-nash, ${ }^{4}$ walaupun Al-Qur'an tidak detail menjelaskan konsep

\footnotetext{
${ }^{2}$ Zuraidah Mohamed Isa, Norhidayah Ali, and Rabitah Harun, "A Comparative Study of Waqf Management in Malaysia," IPEDR:International Conference on Sociality and Economics Development 10 (2011): 561-565. Nilna Fauza, "Rekonstruksi Pengelolaan Wakaf: Belajar Pengelolaan Wakaf dari Bangladesh dan Malaysia," UNIVERSUM 9, no. 2 (July 1, 2015): 161-171, https://doi.org/10.30762/universum.v9i2.83. Baca juga Rahmat Dahlan, "Análisis Kelembagaan Badan Wakaf Indonesia," ESENSI 6, no. 1 (May 17, 2016): 113-24, https://doi.org/10.15408/ess.v6i1.3125.

${ }^{3}$ Taqiyuddin Abi Bakr, Kifayah al Akhyar, 1st ed. (Mesir: Dar al-Kitab al-Araby, tth).319

${ }^{4}$ Muhammad Fuad Abdul Baq̄̄, Al-Mu'jam Al-Mufahras Li Al-Fādh Al-Quran Al-Karim (Mesir: Dar Al-hadist, 2001). 848
} 
wakaf. Tetapi, ada beberapa ayat yang menunjukan makna wakaf, seperti infaq, hiban dan sedekah. Hal itu terdapat dalam Q.S. Ali-Imran [3: 92], Q.S. Al-Baqarah [2:267], Q.S. Al-Hajj [22:77]. Dalam beberapa ayat tersebut Allah menganjurkan kepada hambanya untuk senantiasa menafkahkan sebagian harta kepada orang lain, hal ini menunjukan bahwa Islam merupakan ajaran yang peduli kepada sesama, hanya saja para ulama cenderung mengkaitkan wakaf dengan kata nafakah atau shadaqah.

$$
\text { عن أبي هريرة قال: قال رسول الله صلى الله عليه وسلم: إذا مات الإنسانُ انقطعَ عملُه إلا من ثلاثٍ: صدقةٍِ جاريةٍ، }
$$

Kata dalam hadist tersebut di atas bermakna wakaf, karena wakaf dianggap sebuah amal yang besifat kekal wujudnya dan manfaatnya dapat dirasakan secara terus menerus. Berdasarkan hal itu, para ulama dalam hadis tersebut diatas mentafsikan shadaqah dengan makna wakaf. ${ }^{6}$ Selain dalam al-Quran, dalam beberapa hadis juga dijelaskan tentang wakaf yang dikategorikan kepada hadis wakaf. Hadis merupakan salah satu sumber hukum yang memiliki fungsi sebagai bayān terhadap teks-teks yang terdapat dalam al-Quran. ${ }^{7}$ karena itu, hadis merupakan rujukan penting setelah alQuran bahan menjadi rujukan kedua sealah al-Quran, bahkan hadis juga disebut sebagai wahyu meskipun secara subtansi dan heararki hadis derajatnya dibawah al-Quran kerena hadis merupakan lafad dari nabi sedangkan al-Quran lafal dan makna dari Tuhan. ${ }^{8}$ Meskipun hadis dianggap sebagai wahyu bagi kalangan muslim tradisionalis, tetapi bagi kalangan oraientalis seperti Josehp Schacht yang menganggap bahwa hadis harus dipisahkan dari sunnah karena keduanya memiliki perbedaan secara normatif dan sosiologis. ${ }^{9}$

Pemahaman hadis hingga sekarang masih terjadi perbedaan terhadap penafsiran hadis, hal ini disebabkan oleh perbedaan terhadap memahami hadis Nabi tentang konsep wakaf, secara normatif hadis nabi tidak menjelaskan secara detail terkain dengan pengelolaan wakaf, hanya saja nabi memberikan batasan-batasan terhadap fungsi dan tujuan wakaf yang pada prinsipnya memberikan manfaat kepada orang lain, dalam tulisan ini

\footnotetext{
5al-Nawawi al-Syāfi'i Imam Abi Zakaria bin Syaraf, Riyadus Al-Shālihin (Beirut: Dār Al-Kutub Al-Islāmī, 2010). 280

${ }^{6}$ Sayyid Sabiq, Fiqh Al-Sunnah, vol. III (Mesir: Dâr al-Fath Li 'Ilmi al-‘Arabi, 1997).307

${ }^{7}$ Zul Ikromi, "Fiqh al-Hadits:," Al-Bukhari : Jurnal Ilmu Hadis 3, no. 1 (June 24, 2020): 10529, https://doi.org/10.32505/al-bukhari.v3i1.1534.

${ }^{8}$ Latifah Anwar, "Penulisan Hadis Pada Masa Rasulullah SAW.," Al-Bayan: Jurnal Ilmu alQur'an dan Hadist 3, no. 2 (July 19, 2020): 131-56, https://doi.org/10.35132/albayan.v4i2.88.

${ }^{9}$ Latifah Anwar, "Hadis Dan Sunnah Nabi Dalam Perspektif Joseph Schacht," Al-Bayan: Jurnal Ilmu al-Qur'an dan Hadist 3, no. 2 (July 26, 2020): 174-94, https://doi.org/10.35132/albayan.v4i2.91.
} 
akan mencoba merefleksi kembali terhadap hadis wakaf. Meskipun ada beberapa tulisan yang telah mencoba menjelaskan wakaf dengan pendekatan hadis, misalnya tulisan Nurodin tentang "kajian hadis wakaf dalam kitab Bukhari dan Fath al-Bari" dalam tulisan ini menjelaskan bahwa hadis tentang wakaf tidak dibahas secara luas, sehingga pemaknaannya tidak mampu menjawab tantangan zaman modern saat ini. Selanjutnya tulisan Muhammad Nuruddin dengan judul "Memahami Hadis Wakaf Dalam Konstalasi Masyarakat Global" dalam tulisan ini menjelaskan bahwa wakaf memiliki peran penting dalam perkembangan ekonomi ummat apabila dikelola dengan baik.

Dalam tulisan ini akan menganalisis makna hadis baik secara leksikal maupun historikal dengan pendekatan sosiologis. Penelitian ini merupakan penelitian normatif dengan menela'ah kitab hadis yang berkaitan dengan hadis hukum tentang wakaf. Untuk memperkaya data dalam tulisan ini juga menggunakan data-data hasil penelitian baik itu yang bersifat normatif maupun sosiologis.

\section{Hasil dan Pembahasan: Refleksi Terhadap Redaksi Hadis Wakaf}

Terdapat beberapa hadis terkait dengan wakaf baik dijelaskan secara teks maupun secara konteks, berdasarkan penelusuran ditemukan kurang lebih 100 lebih hadis yang secara teks menggunakan kata waqafa baik itu dari bentuk fi'il madhi, mudhari' atau jama'. ${ }^{10}$ Hanya saja, dalam beberapa hadis kata habasa, hamala dan shadaqah terkadang menunjukan makna wakaf seperti;

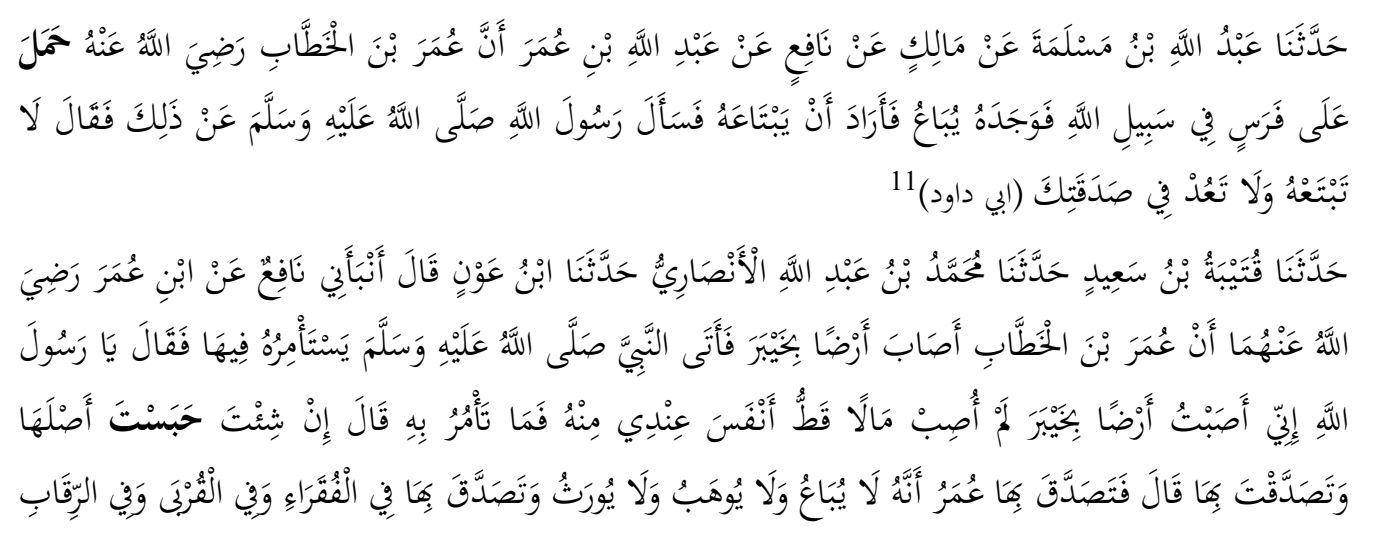

${ }^{10}$ J.P. Mensing A.J. Wensinck and Brugman J, Al- Mu'jam al-Mufahras Li al-Fädhi al-Hadis al-Nabawī 1st ed. (Leiden: E.J. Brill, 1969). 290

${ }^{11}$ Shidqi Hamil al-'Athar, Sunan Abi Dāwud, (Beirut: Dār al-Fikr, 2003), 39. 


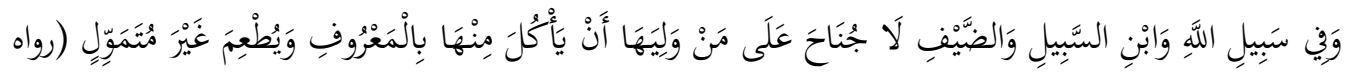

$$
\begin{aligned}
& 12 \text { البخاري } \\
& \text { روي عن عمر بن شبه عن عمر بن سعد بن معاد قال : سألنا عن أول حبس في الإسلام، فقال المهاجرون } \\
& \text { صدقة عمر، وقال الأنصار صدقة رسول الله صلى الله عليه وسلم } 13
\end{aligned}
$$

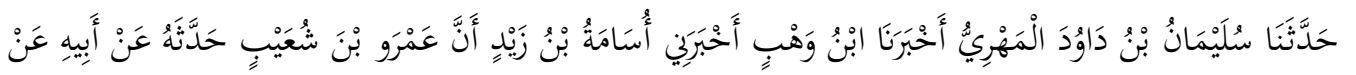

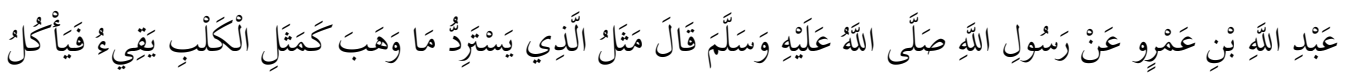

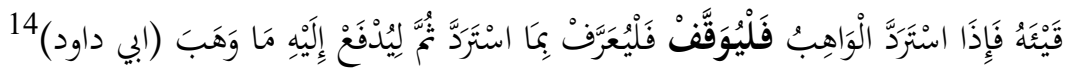

Fokus kajian hadis dalam tulisan ini yaitu hadis tentang wakaf riwayat Imam Bukhari tentang tanah wakaf di Khaibar, pemilihan hadis tersebut karena hadis ini menjadi salah satu rujukan bagi para Imam Mazhab tentang ketentan hukum dan pengelolaan wakaf, bahkan Ibn Hajar menyatakan bahwa hadis tersebut merupakan dasar hukum syariat tentang wakaf. ${ }^{15}$ Adapun bunyi hadis tersebut yaitu;

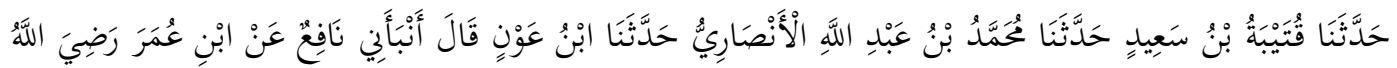

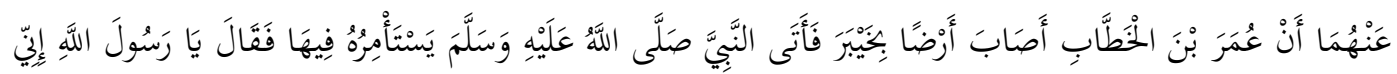

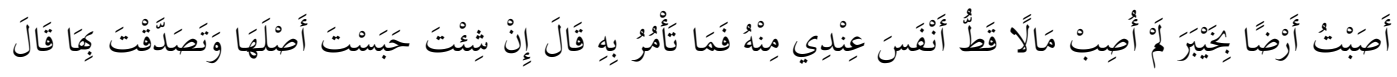

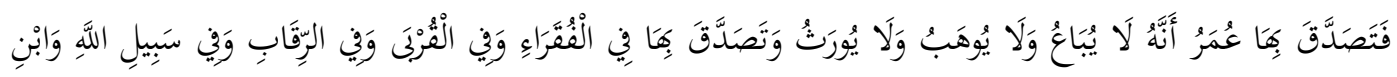

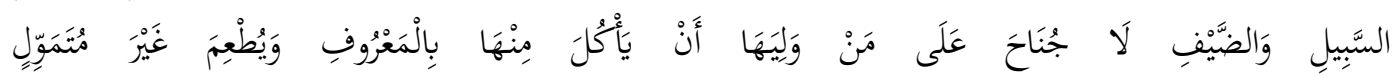
(رواه البخاري)

Berdasarkan kitab Al- Mu'jam al-Mufahras Li al-Fādhi al-Hadis alNabawī hadis tentang wakaf terdapat dalam beberapa kitab hadis, antara lain; pada kitab shahih Bukhari bab syurūth nomor hadis 19, washāya nomor hadis 28 dan pada bab iman dengan nomor hadis 33. Selanjutnya kitab sunan Abu Dāwud bab washāya dengan nomor hadis 16, pada kitab sunan at-Tirmidzi bab ahkam nomor hadis 26, sunan Nasa'i bab ihbas nomor hadis 2, shahih Muslim bab washāya nomor hadis 15, sunan Ibn Majah bab shadaqah nomor hadis 4 dan musnad Ahmad nomor hadis 2, 11 dan $16^{16}$ dan Sunan Dāruquthnī kitab ahbas nomor hadis 4333. Berdasarkan temuan

\footnotetext{
${ }^{12}$ Muhammad Ibn al-Bukhari, Shahih Al-Bukhāri, 3rd ed. (Beirut: Dār al-Fikr, 1981).185. lihat juga Ibnu Hajar Al-Asqalani, Fathu Al-Bari, 5th ed. (Beirut: Dār al-Fikr, 2000).709

${ }^{13}$ Ibn Hajar al-Asqalani, Fathul Al-Bari Syarh Shahih al-Bukhāri, 5th ed. (Riyadh: Maktabah alMalik Fahd al-Wathaniyah, 2001).472

14 al-'Athar, Sunan Abi Dāwud,

15 Nurodin Usman, "Studi Hadis-Hadis Wakaf Dalam Kitab Sahih Al-Bukhari Dan Fath AlBari," CAKRAWALA 10, no. 2 (2015): 19.

${ }^{16}$ A.J. Wensinck and J, Al-Mu'jam al-Mufahras Li al-Fadhi al-Hadis al-Nabawi..416
} 
tersebut bahwa matan hadis memiliki kesamaan lafadz hanya saja perbedaan terletak pada jalur sanadnya saja, antara lain;

a. Redaksi Hadis Dalam Musnad Ahmad

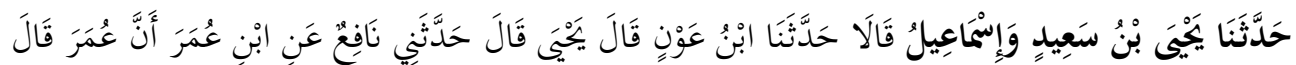

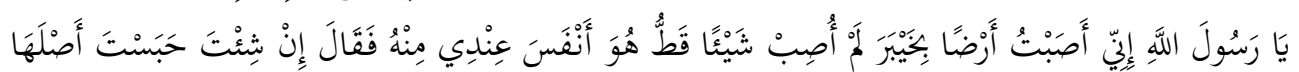

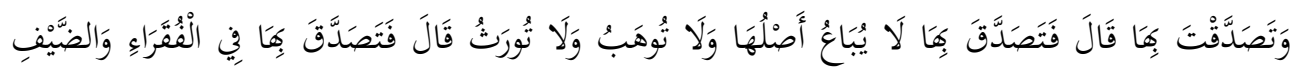

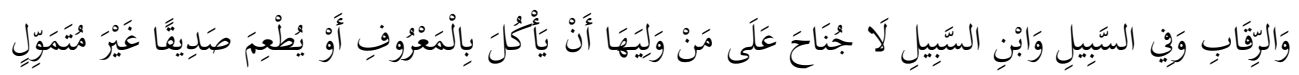

b. Redaksi Hadis Dalam Shahih Muslim

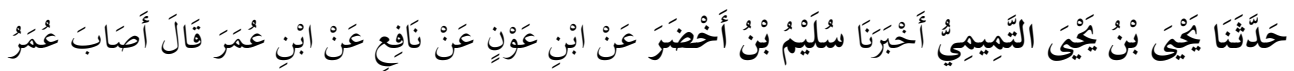

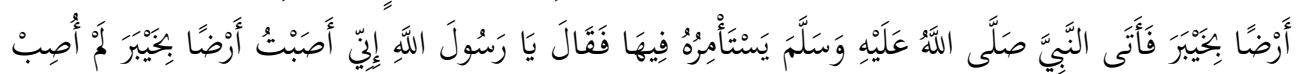

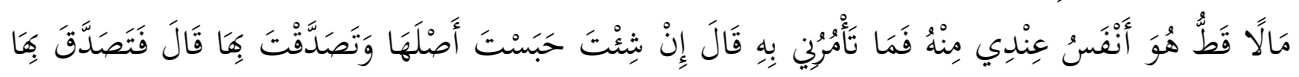

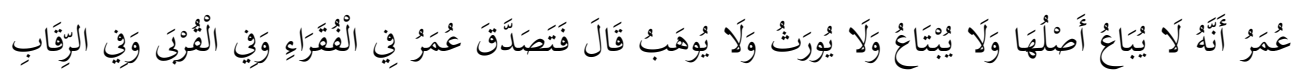

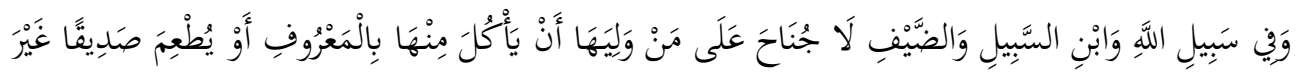

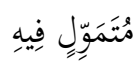

c. Redaksi Hadis Dalam Sunan Daruquthnī

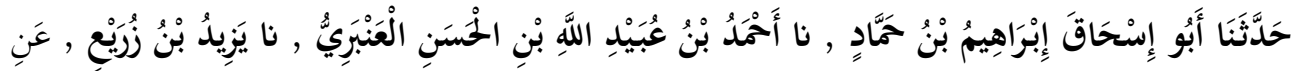

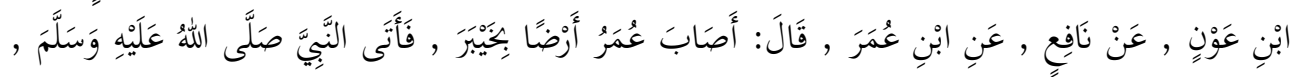

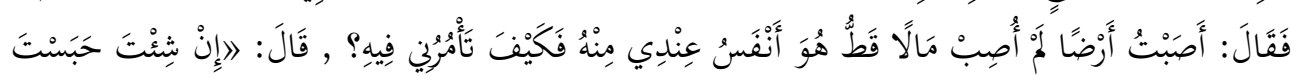

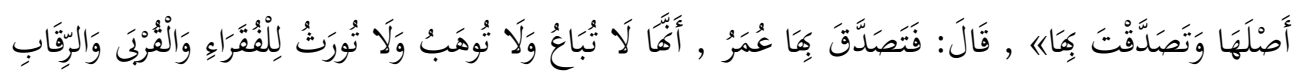

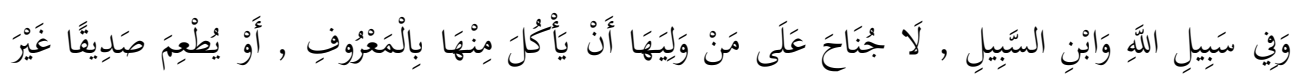

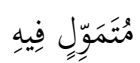

d. Redaksi Hadis Dalam Sunan at-Tirmidzi

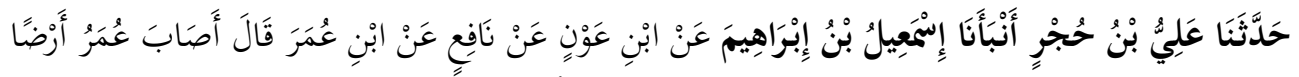

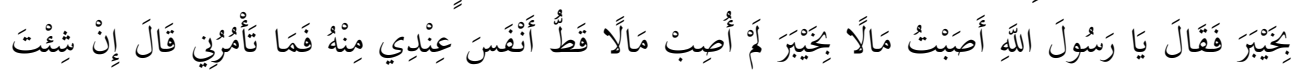

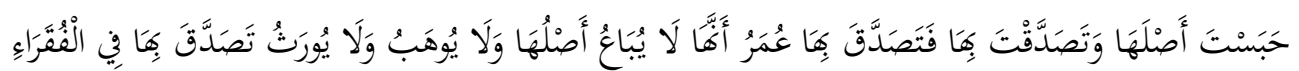

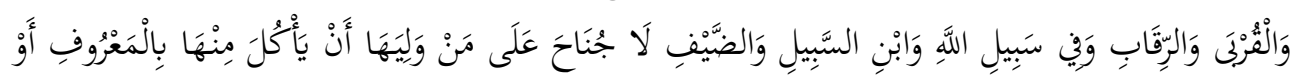

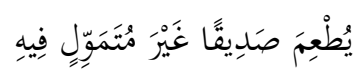

e. Redaksi Hadis Dalam Sunan Abu Dāwud

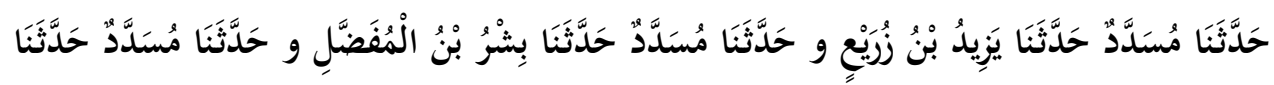

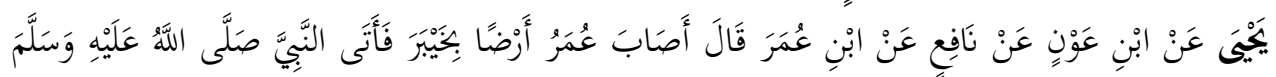

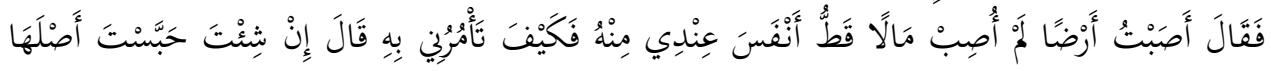




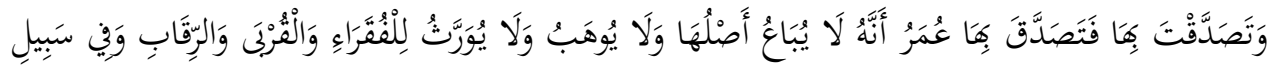

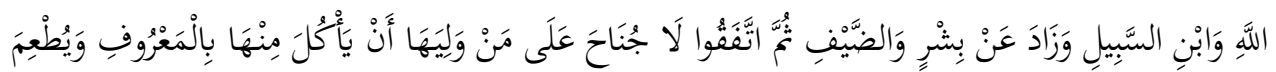

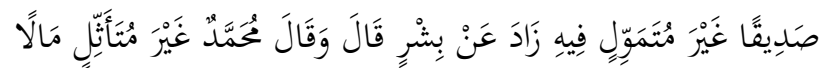

f. Redaksi Hadis Dalam Sunan Ibn Majah

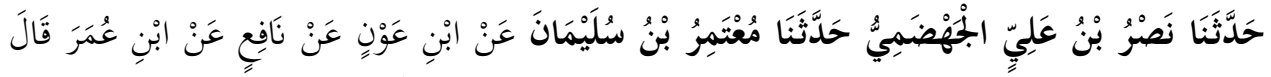

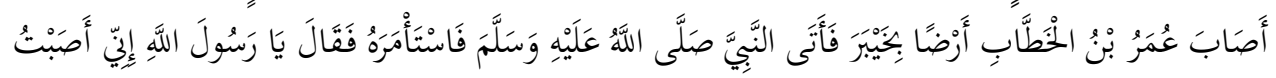

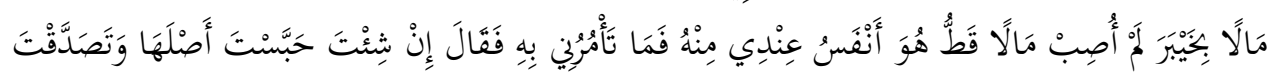

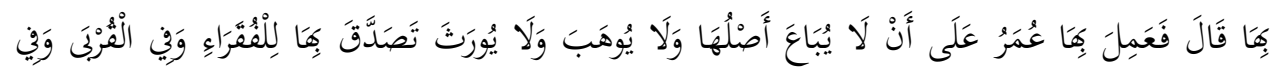

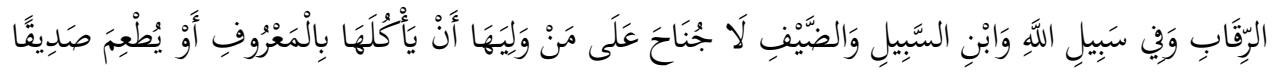

$$
\begin{aligned}
& \text { غَيْرَ مُتَتَمَِّ }
\end{aligned}
$$

g. Redaksi Hadis Dalam Sunan Nasa'i

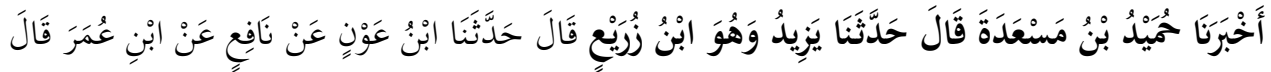

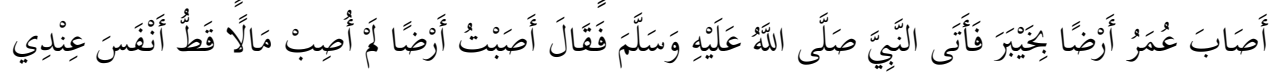

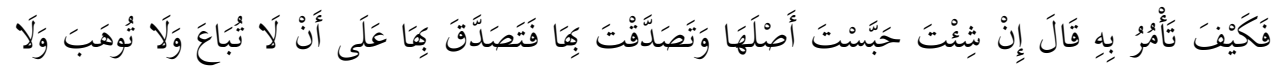

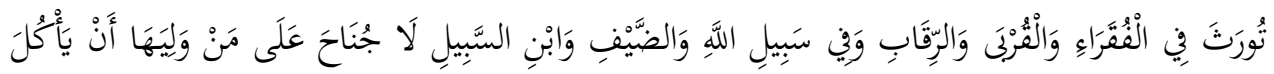

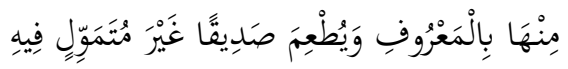

Berdasarkan beberapa redaksi hadis diatas menunjukan bahwa terdapat perbedaan jalur sanad antara perawi hadis, hal ini dimungkinkan karena para sahabat secara langsung berjumpa dengan Rasul dan para perawi hadis betemu dengan para sahabat yang berbeda-beda, hanya saja yang membedakannya adalah kualitas sanad dan kebersambungan hadis yang diriwayatkan. Keberadaan sanad dalam hadis sangat penting untuk menjada orisinalitas hadis sehingga tidak diragukan lagi keberadaannya. Oleh kerana itu, kualitas hadis cukup mempengaruhi bagaimana perawi hadis dalam menghimpun hadis, ${ }^{17}$ Bukhāri merupakan salah satu perawi hadis yang sangat ketat dalam penghimpunan hadis sehingga kualitas hadisnya tidak diragukan lagi oleh para ulama hadis.

\section{Tinjauan Sanad Hadis}

Kritik sanad bertujuan untuk melihat kualitas sanad hadis baik dari segi moralitas maupun kualitas personal, bukan berarti ingin melemahkan hadis yang telah dihimpun oleh para ulama hadis melainkan untuk mempertegas bahwa keshahihan hadis sehingga terhindar dari fitnah yang dapat

${ }^{17}$ Andi Rahman, "Pengenalan Atas Takhrij Hadis," Riwayah : Jurnal Studi Hadis 2, no. 1 (March 29, 2017): 146, https://doi.org/10.21043/riwayah.v2i1.1617. 
melemahkan dan meragukan validitas hadis. ${ }^{18}$ Pendekatan kritik hadis juga bertujuan untuk menghilangkan stigma keraguan baik muslim maupun nonmuslim dalam mengamalkan hadis.

Kritik sanad pada hadis wakaf setelah melalui proses penelusuran hadis menunjukan bahwa jalur sanad hadis yang di takhrij oleh Bukhāri ini melalui jalur sanad 'Umar bin Khattab, Ibn 'Umar, Nāfi', Ibn 'Aun, Qutaibah, Muhammad bin 'Abdillah dan Bukhāri. Untuk lebih jelasnya mengenai kritik sana maka akan dijelaskan kualitas masing-masing sanad;

\section{Umar Bin Khattab}

Umar bin Khattab memiliki nama lengkap Umar bin Khattab bin Nufail bin Abdul Izzy bin Razah bin Qirath bin Razah bin 'Adi bin Ka'ab bin Lu'ya al-'Adawy, dikenal juga dengan julukan Umar Faruq. Umar dilahirkan dari seorang ibu yang bernama Hantimah binti hasyim bin al-muqirah almahzumiyah. Penggilan umar faruq merupakan gelar yang diberikan oleh rasul kepada umar sebagaimana hadis riwayat at-Tirmidzi bahwa jin takut kepada Umar:

Umar adalah sahabat Nabi yang sudah mendapatkan legitimasi dari nabi akan masuk surga, selain itu umar juga merupakan tokoh yang dikenal sebagai panglima perang sekaligus pemimpin yang memiliki kehati-hatian dalam periwayat hadis, umar juga mengeluarkan kebijakan ketika menjadi khalifah untuk tidak memperbanyak hadis karena dikhwatirkan akan terjadinya terjadinya hadis palsu. ${ }^{19}$ Umar juga merupakan salah satu sahabat periwayat hadis yang terkenal dengan jumlah 2630 hadis.

\section{Ibnu Umar}

Memiliki nama lengkap Abdullah bin 'Umar bin Al Khathab bin Nufail bin 'abdil 'Azī bin riyāh bin Qirath bin razāh bin 'Adī bin Ka'ab bin Lu'ya bin al-'Adawy dan wafat pada tahun $73 \mathrm{H}$. Ibnu Umar memeluk Islam saat usianya masih kecil dan banyak meriwayatkan hadis dari ayahnya, bilal, 'Aisyah dan lainnya, sehingga tidak diragukan lagi bahwa Ibnu Umar mendapatkan hadis langsung dari pelaku hadis.

Berkaitan dengan kualitas sananya, Ibnu Zubair mengatakan bahwa Ibnu Umar memiliki kualitas tsubut, Ibnu Mas'ud menambahkan bahwa Ibnu Umar merupakan orang yang ta'at beribahadah kedapa Allah. Abu Na'im menyatakan bahwa ia adalah sorang yang häfild, Ibnu Muhīrīz menyatakan

\footnotetext{
18 Suryadi, "Rekonstruksi Kritik Sanad Dan Matan Dalam Studi Hadis," Esensia: Jurnal IlmuIlmu Ushuluddin 16, No. 2 (October 1, 2015): 177, Https://Doi.Org/10.14421/Esensia.V16i2.996.

${ }^{19}$ Leni Andariati, "Hadis dan Sejarah Perkembangannya," Diroyah : Jurnal Studi Ilmu Hadis 4, no. 2 (April 13, 2020): 154-66, https://doi.org/10.15575/diroyah.v4i2.4680.
} 
bahwa Ibnu Umar adalah orang yang terpercaya dan banyak keutamaan terdapat padanya. ${ }^{20}$

\section{Nāfi'}

Nama lengkanya yaitu Nāfi' merupakan orang yang faqih memiliki guru langsung kepada abī Hurairah, Ibnu Umar, 'Aisyah dan sahabat lainnya, Nāfi' juga memiliki murid Abū Umar, Abdullah Bin Dīnār, Shalih bin Kīsān dan masih banyak lagi. Berdasarkan penulusuran sanad hadis ditemukan bahwa kualitas sanadnya tsiqah, sebagaimana yang diutarakan oleh Ibnu Sa'id, al'Ajalī, Ibn Kharāsy dan Nasā'î, bahkan al-Bukhārī menambahkan bahwa jalur sanad dari Nāfi' lebih shahih. Berkaitan dengan wafatnya ada beberapa perbedaan pendapat, Yahya mengatakan bahwa Nāfi' wafat pada tahun 117 $\mathrm{H}$, Ibnu 'Uyainah menyatakah $190 \mathrm{H}$ dan Abu 'umar menyatakan $120 \mathrm{H}^{21}$

\section{Ibn 'Aun}

Memiliki nama lengkap 'Abdullah bin 'Aun lahir lahir di Bashra, usia 85 tahun dan wafat tahun 150 H. memiliki guru Al-Hasan, Nāfi', Al-Qāsim bin Muhammad. Berkaitan dengan kualitas Ibn 'Aun, Ibn Sa'ad menyatakan bahwa Ibnu 'Aun memiliki kualitas sanad stiqah,wira'. Shaleh dan Ibn alMubārak menyatakan juga bahwa saya tidak pernah menyaksikan orang sebaik 'Aun. Hal ini seperi apa yang diutarakan Ruh Ibn 'Ubadah bahwa saya tidak pernah menyaksikan hamba yang shalih seperti 'Aun.

\section{Muhammad bin 'Abdi}

Memiliki nama lengkap Abū 'Abdillah Muhammad bin 'Abdillah bin AlMutsanna bin 'Abdillah bin Anas bin Malik, lahir pada tahun $118 \mathrm{H}$ dan wafat pada tahun $215 \mathrm{H}$ dengan usia 97 Tahun. Berdasarkan penulusuran menunjukan bahwa Muhammad bin 'Abdi memiliki kualitas stiqah sebagaimana yang dikatakan oleh Abū Hātim al-Rāzì, an-Nasāì mengkategorikan kedalam drajat laisa bi ba's, Abū Dāwud menambahkan bahwa ia adalah orang yang 'Ālim.

\footnotetext{
${ }^{20}$ Ibnu Hajar Al-Asqalani, Tahdzib Al-Tahdzib, 4th ed. (Beirut: Dār al-Fikr, 1995).406-407

${ }^{21}$ Ibnu Hajar Al-Asqalani, Tahdzib Al-Tahdzib, 8th ed. (Beirut: Dār al-Fikr, 1995).474
} 


\section{Qutaibah bin Sa'īd}

Memiliki nama lengkap Qutaibah bin Sa'īd bin Jamīl bin Tharîf alTsaqafī lahir pada tahun $149 \mathrm{H}$ dan wafat pada tahun $240 \mathrm{H}$ dengan usia 90 tahun, dalam kontek hadis tentang wakaf, Qutaibah memiliki kebersambunagan sanad dengan gurunya Muhammad bin 'Abdi dan muridnya al-Bukhārī. Berkaitan dengan kualitas sanadnya, Yahya bin Mu'īn mengatakan bahwa Qutaibah memiliki kualitas stiqah sama dengan pendapatnya Abū Hātim al-Rāzī, an-Nasā'ī dan Ibn Kharāsy menyatakan bahwa Qutaibah memiliki kualitas Shuduq.

Berdasarkan penelusuran sanad hadis perlu diketahui bahwa secara teoritis dan praktis ada beberapa ilmu berkaitan dengan penilaian kualitas hadis, ilmu tersebut dekenal dengan istilah al-jarh wa al-ta'dil yang merupakan suatu keilmuan untuk mengetahui kualitas perwi yang berbicara tentang sifat, karakter serta intelektualitasnya. ${ }^{22}$ Ada beberapa kriterian ta'dil dalam menentukan kualitas tingkatan rawi sanad.

a) Menggunakan sighat mubalaghah atau mengikuit wazan إفعل, pada posisi ini para rawi memiliki tingkatan tertinggi.

b) Dengan menggunakan kata pujian dengan pengulangan atau diikuti kata yang sama, seperti : stiqah stiqah.

c) Kata pujian tanpa pengulangan, seperti : stiqah

d) Kata yang menunjukan kebaikan tanpa diikutsertakan dengan kualitas inteletualnya, seperti : shuduq atau la ba'sa bih.

Berdasarkan teori diatas, setelah dicermati dari data-data yang dikumpulkan dari kitab hadis yang berghubungan dengan penelitian hadis ini, dari dari data tersebut menjelaskan bahwa secara keseluruhan hadis tersebut memiliki perawi yang berpredikat stiqah, bahkan ada ulama hadis yang menyatakan stiqah nabïl, tetapi setelah diteliti dan dikorelasikan dengan al-jarh wa ta al-ta'dil dalam kitab Tahdzib Al-Tahdzib, secara keseluruhan mereka menempati posisi kedua, ketiga dan keempat.

Pada aspek kebersambunagan perawi, maka dapat disimpulkan bahwa keseluruhan perawi setelah melalui proses penelitian, maka hadis ini memiliki ittishalu al-hadis atau muttashil, dan hadis ini juga diriwayatkan dalam hadis lainnya yang tidak diragukan lagi kualitas hadisnya, oleh karena itu. Penulis mencermati bahwa sanad hadis tersebut berkualitas shahih dan maqbul al-hujjah. Dan secara teoritis juga dijelaskan bahwa hadis memiliki tingkatan shahih ketika memiliki beberapa kriteria, antara lain; Pertama, terjadi ketersambungan sanad dengan Nabi Muhammad malai dari sana dan

${ }^{22}$ Umi Sumbulah, Kritik Hadits, Pendekatan Historis Metodologis (Malang: UIN Malang Press, 2008). 78 
mukharijul hAdist; kedua, periwayat hadis memiliki kualitas dhabit dan 'adil; ketiga, sanad dan matan terhidar dari shadzudz illat. ${ }^{23}$

\section{Kritik Terhadap Redaksi Matan Hadis}

Kritik matan dilakukan untuk melihat dan mencermati kualtas matan hadis dan menggali makna hadis serta memadukan dengan hadis-hadis yang lain guna untuk mengetahi apakah terjadi mukhtalif al-Hadis dengan hadis yang lainnya. Hadis lain tentang wakaf yang melalui jalur sanad Umar bin Khattab memang terdapat perbedaan sanad dengan hadis yang diriwayatkan oleh para perawi hadis lainnya, hal ini membuktikan bahwa tidak terjadinya pertentangan matan hadis dengan hadis lainnya bahkan bahkan dengan kesesuaian baik lafald dan makna matan hadis tersebut dengan hadis yang lain dapat memperkuat keshahihan matan hadis tersebut.

Jika kita hubungkan dengan fakta sejarah, secara historis hadis ini diturunkan (asbabul wurud) ketika 'umar bin Khattab memiliki tanah di daerah Khaibar yang memiliki nilai jual sebanyak 100 dirham, dalam kanteks ekonomi pada masa itu nilai 100 dirham merupakan nilai yang tinggi dan banyak ditambah lagi tanah tersebut subur, dampaknya orangorang disekitar tanah Khaibar berebut untuk memilikinya, melihat kondisi tersebut 'Umar menemui Rasulullah untuk meminta pedapatnya tentang tanah tersebut. Menyikapi hal tersebut, Rasulullah memberikan arahan dengan cara menahan tanah dan mewakafkannya sehingga manfaat dari tanah tersebut dapat dirasakan oleh orang banyak dan tinah tersebut tidak dapat dijual atau dihadiahkan dan diwariska. ${ }^{24}$

Wakaf yang telah dilakukan oleh Umar kemudian disusul dengan praktek wakaf yang diaplikasikan oleh Thalhah Ubaidillah yang mewakafkan sebidang tanahnya, Ustman bin Affan menyedekahkan harta kekayaannya di Khaibar, Ali bin Abi Thalib juga mewakafkan tanah suburnya dan juga sederet nama sahabat Rasulullah yang masyhur seperti Abdullah bin Umar, Anas bin Malik, Zubair bin Awwam serta Ummul Mukminin Siti Aisyah. ${ }^{25}$

Ada beberapa kata kunci yang terdapat dalam hadis wakaf tersebut yaitu kata حَبَنْ yang memiliki makna "menahan". ${ }^{26}$ Para ulama fiqh

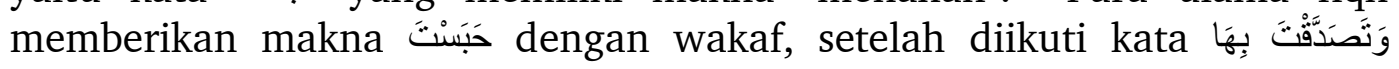

\footnotetext{
${ }^{23}$ Zubaidah, "Metode Kritik Sanad Dan Matan Hadits," Jurnal Komunikasi Dan Pendidikan Islam 4, no. 1 (June 2015): 43-80.

${ }^{24}$ Muhammad Nurudin, "Memahami Hadis Wakaf Dalam Konstalasi Masyarakat Global," Junal Zakat dan Wakaf 2, no. 1 (2015): 25.

${ }^{25}$ Ibn Rusyd, Bidāyah Al-Mujtahid Wa Nihāyah al-Muqtashid, vol. 2 (Mesir: Mathba'ah alBabiy al-Halabiy, 1960).193

${ }^{26}$ Muhammad Jawad Mughniyah, Fiqih Lima Mazhab: Ja'fari, Hanafi, Maliki, Syafi'i, Hambali. (Shaf, 2015).635
} 
maksudnya setelah menahannya lalu menyedekahkan tanah tersebut, tidak cukup disitu rasul menambahkan lagi kata لَا يُبَاعُ وَلَا يُوََبُ وَلَا يُورَثُ yang

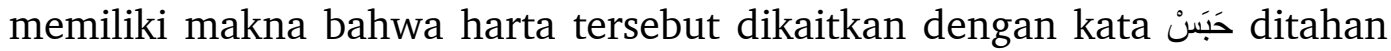
tidak diperbolehkan untuk di jual, dihadiahkan dan diwariskan. Selanjutnya makna وَتَصَدَّنَ memiliki makna bahwa yang disekahkan yaitu berupa buah atau manfaat dari tanah tersebut, ini merupakan tujuan makna dari kata وَتََصَدَّقَ الْفُقَرَاءِ mengarahkan bahwa objek dari wakaf tersebut adalah

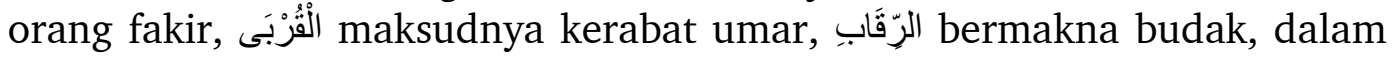
hal ini masih terjadi perbedaan dikalangan ulama fiqh terkait dengan budak. Kalimat وَفِي سَبِيلِ اللَّهِ maksud dari lafald ini yaitu orang yang berjihat dan termasuk juga orang yang naik haji. Kalimat وَابْنِ السَّبِيلِ yakni orang yang sedang melakukan perjalanan jauh yang tidak bertentangan dengan syariat, sedangkan kalimat وَالضَّيَفِ tamu atau orang yang datang dari daerah lain.

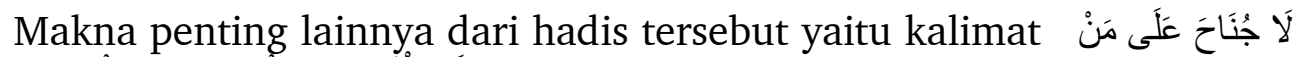

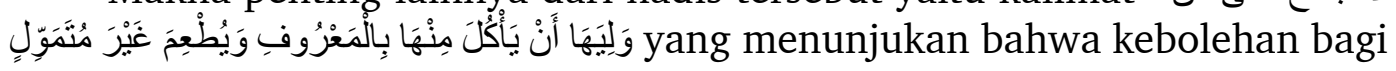
pengelola untuk memakan dari harta tersebut yang disesuaikan dengan kondisi maksudnya tidak terjadi penumpukan harta. Hadis riwayat Bukhâri juga dikuatkan dengan al-quran dan hadis-hadis yang lain. Dalam al-Quran Allah berfirman QS. Al-Baqarah: 261 yang memiliki makna bahwa saling memiliki kepedulian sesama dalam kebaikan dan tidak dalam keburukan. Sedangkan Hadis pendukung wakaf adalah hadis yang diriwayatkan oleh Imam Muslim dari Abu Hurairah tentang tiga hal yang bersifat abadi yang mengandung pahala jariyah oleh orang yang telah meninggal sebagaimana hadis riwayat Muslim: ${ }^{27}$

$$
\text { جارية أو علم ينتفع به أو ولد صالح يد أنه صلى الله عليه وسلم قال : إذا مات ابن الانسان انقطع عنه عمله إلا من ثلاثة: صدقة مسلم) }
$$

Hadis ini menjadi pegangan kuat oleh pakar-pakar hukum Islam sebagai landasan kuat dalam pembentukan wakaf. Sedekah jariyah yang dimaksudkan dalam hadist ini adalah harta yang diwakafkan yang pahalanya mengalir secara terus-menerus, selama benda wakaf itu ada dan dimanfaatkan. ${ }^{28}$

\section{Aktualisasi Hadis wakaf dan Penerapannya di Indonesia}

Berdasarkan hadis tersebut dapat dipahami bahwa praktik wakaf di sunnahkan, bahkan pada masa Rasul dan sahabat sudah menjadi suatu

\footnotetext{
${ }^{27}$ Muslim bin Hajjaj, Shahih Muslim (Beirut: Dār Al-Kutub Al-'Ilmiyah, tth). 1225

${ }^{28}$ Mukhtar Luthfi, Optimalisasi Pengelolaan Wakaf, 1st ed. (Makasar: Alauddin Press, 2011).56-57
} 
kebiasaan bahkan sudah menjadi hal yang lumrah bagi setiap sahabat yang memiliki kelebihan. Bahkan tidak tersisa harta para sahabat karena senang dan gemar dalam mewakafkan hartanya. Sehingga hingga kini wakaf menjadi salah satu amalan bagi kaum dermawan yang memiliki kelebihan harta. Bahkan Mushtafa menyatakan bahwa: ${ }^{29}$

$$
\begin{aligned}
& \text { وقد اشتهر الوقف بين الصحابة وانتشر، حتى قال جابر رضي الله عنه: ما بقى أحد من أصحاب رسول الله - } \\
& \text { صلى الله عليه وسلم - له مقدرة إلا وقف. وقال الشافعي رحمه الله تعالى: بلغني أن ثمانين صحابياً من الأنصار }
\end{aligned}
$$

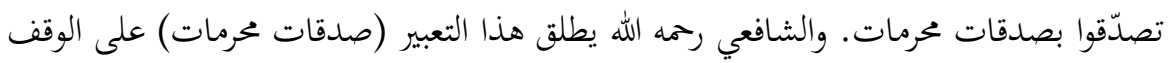

Dapat dipahami bahwa praktik wakaf pada masa Rasul dan sahabat sudah menjadi suatu kebiasaan bahkan sudah menjadi hal yang lumrah bagi setiap sahabat yang memiliki kelebihan. Bahkan tidak tersisa harta para sahabat karena senang dan gemar dalam mewakafkan hartanya.

Pada masa dinasti Umayyah dan dinasti Abbasiyah, praktek perwakafan menjadi semakin banak dilakukan. Peruntukan wakaf tidak hanya mengarah kepada personal kaum muslimin, tetapi juga sudah mulai menyentuh lembaga-lembaga sosial keagamaan seperti lembaga pendidikan, perpustakaan Islam, juga menjadi sarana untuk membayar gaji tenaga pengajar serta memberi beasiswa kepada anak didik. ${ }^{30}$

Selanjutnya, perkembangan wakaf sangat menggairahkan terjadi pada dinasti Ayyubiyah di Mesir. Pada saat itu mayoritas tanah pertanian menjadi harta wakaf dan dikelola oleh negara dibawah baitul mal. Pada saat Salahuddin al-Ayyubi memerintah Mesir, beliau mengambil kebijakan yaitu menyerahkan aset wakaf kepada orang yag dipercayai dan berkompeten untuk mengelola harta wakaf dan manfaatnya diberikan kepada seluruh kaum muslimin pada waktu itu.

Banyak harta milik negara terutama yang berbentuk lahan kosong diwakafkan oleh Salahuddin al-Ayyubi untuk dipergunakan dalam kegiatan pendidikan dengan membangun Madrasah, Begitu juga kesejahteraan bagi ulama, beliau memerintahkan kepada non muslim yang datang untuk berdagang dari wilayah Iskandariyah untuk membayar bea cukai. Selanjutnya, bea cukai tersebut dipergunakan dan disalurkan kepada ulamaulama dan keluarganya untuk mencukupi kebutuhan hidup mereka seharihari.

\footnotetext{
${ }^{29}$ Mushtafa al-Khin, Al-Fiqh al-Manhajī 'Alā Mazhab Imām al-Syāfi'i, 5th ed. (Beirut: Dār alQalam, 1992).11

${ }^{30}$ Nashiruddin Rachmat, Harta Wakaf: Pengertian, Perkembangan Dan Sejarahnya Didalam Masyarakat Islam Dulu Dan Sekaran (Jakarta: Bulan Bintang, 1964).62
} 
Semenjak abad kelima belas, emperium Turki Usmani melakukan ekspansi wilayah dan menyebabkan wilayah Arab masa itu dikuasai oleh dinasti tersebut. Kekuasaan politik yang telah berhasil di raih oleh emperium ini, menjadikan akses untuk menegakkan syariat Islam semakin mudah, dan salah satu aspek yang paling berkembang adalah masalah wakaf. Diantara peraturan-peraturan tentang perwakafan yang ada pada masa emperium Turki Usmani. ${ }^{31}$

Perkembangan wakaf di dunia Islam tersebut, kita dapat melihat bahwa sejak masa Rasulullah hingga saat ini, wakaf tetap eksis bahkan terus berkembang begitu juga halnya di Indonesia yang notabene sebagai negara dengan jumlah muslim terbesar. Menelisik dari realita dikalangan masyarakat, bahwa wakaf yang notabene berasal dari agama Islam telah di resepsi oleh bangsa Indonesia menjadi hukum adat, juga menjadi sebuah keniscayaan bahwa objek wakaf di Indonesia sangat banyak, baik wakaf dengan harta benda yang bergerak, maupun benda yang tidak bergerak.

Hadis yang diriwayatkan Bukhâri tentang wakaf merupakan dalil yang menjelaskan tentang syarat-syarat wakaf, sehingga dari dalil tersebut dapat dipahami bahwa ada prinsip-prinsip yang harus dipenuhi ketika berwakaf;

1. Larangan menjual aset wakaf, dihadiahkan, diwariskan.

2. Harta wakaf tidak berubah bentuknya dan bersifat tetap.

3. Yang diambil adalah manfaat bukan wujud benda.

4. Objeknya yaitu masyarakat baik itu, fakir, kerabat, fisabilillah, ibnu sabil dan musafi.

5. Hadis tersebut juga menghendaki adanya Nāzhir wakaf.

6. Nāzhir dibolehkan untuk mengambil manfaat dari harta wakaf.

Berdasarkan hadis ini pula para ulama fikih menyusun ketentuan hukum wakaf, sehingga aspek hukum dalam fikih baik itu rukun dan syarat harus terpenuhi. Adapun rukun yang harus dipenuhi untuk sahnya wakaf adalah sebagai berikut: Pertama, Wākif (orang yang mewakafkan harta). Seorang wākif disyaratkan harus merupakan orang yang cakap melakukan tindakan hukum. Wākif juga harus terbebas dari halangan melakukan tindakan hukum, seperti gila, atau dalam penguasaan orang lain. Jumhur berpendapat bahwa orang yang bodoh dan pailit tidak sah melakukan perwakafan. Ulama Hanafiyah juga mensyaratkan wākif bukanlah orang yang pailit kecuali mendapat izin dari krediturnya. ${ }^{32}$ Kedua, Mauquf bih (benda wakaf). Ketiga, Mauquf 'alaih (objek wakaf) dan keempat, Sighat Wakaf.

\footnotetext{
${ }^{31}$ Direktorat Pemberdayaan Wakaf Departemen Agama RI, Fiqih Wakaf (Jakarta: : Direktorat Pemberdayaan Wakaf Departemen Agama RU, 2006).10

${ }^{32}$ Wahbah Zuhaili, Al-Fiqhu al-Islamī Wa 'Adillatuhu, 6th ed. (Damaskus: Dār al-Fikr alMu'āshir, 2008).134
} 
Dinamika praktik wakaf di Indonesia, baik dari sisi tekstual maupun kontekstual, tidak lepas dari dinamika Islam maupun dinamika konteks yang terjadi pada saat ini. Pada awal Islam masuk ke Nusantara, wakaf identik dengan kebutuhan ibadah dan dakwah sehingga kegiatan wakaf yang ada terbatas dan hanya diorientasi untuk kegiatan keagamaan saja, seperti pembangunan masjid, mushalla, madrasah, perkuburan dan sarana ibadah lainnya.

Di Indonesia sendiri, wakaf telah dikenal dan dipraktikkan oleh umat Islam sejak agama Islam masuk Indonesia (Nusantara) pada abad $15 .^{33}$ Wakaf pada saat ini masih berkisar wakaf tanah, di Aceh wakaf tanah pernah terjadi pada tahun 1809 Masehi yang dikenal dengan wakaf Baitul Asyi. Dalam kilasan sejarah Baitul Asyi merupakan wakaf Habib Bugak Asyi yang berada di Arab Saudi dan terdaftar sebagai aset wakaf untuk masyarakat Aceh pada tahun 1224 Hijriah atau 1809 Masehi dengan tujuan agar dapat digunakan sebagai pemondokan warga Aceh yang akan menunaikan ibadahhaji atau yang belajar di Makkah (Arab Saudi). ${ }^{34}$ Selain itu, bagi masyarakat Aceh yang pergi haji mendapatkan uang kompensasi setiap individu dari Baitul Asyi sebesar 1.200 Riyal yang setara dengan Rp 4,5 juta. $^{35}$

Lambat-laun wakaf terus bergulir dikalangan masyarakat Islam Indonesia, permulaan konsep wakaf di Indonesia dapat dikatakan sejalan dengan perkembangan penyebaran Islam. Pada masa-masa awal pensyiaran Islam, kebutuhan terhadap masjid begitu besar, karena masjid merupakan tempat terpenting untuk beribadah bagi ummat Islam, sehingga mendorong orang-orang yang memiliki kelebihan harta mewakafkan tanahnya untuk dibangun masjid. Lambat-laun paradigma "orientasi wakaf adalah tanah untuk masjid" tetanan pada sebagian masyarakat Indonesia dan sudah menjadi tradisi yang lazim dan meluas bagi komunitas-komunitas Islam di Indonesia. Faktanya berdasarkan penelitian yang dilakukan oleh Aam Slamet Rusydiana dan Salman Al-Farisi dengan menela'ah 100 jurnal tentang wakaf menunjukan bahwa manyoritas praktik wakaf di Indonesia didominasi oleh wakaf non-tunai sebasar 62 persen sedangkan sisanya 38 persen merupakan wakaf tunai. ${ }^{36}$

\footnotetext{
${ }^{33}$ Suryani Suryani and Yunal Isra, "Wakaf Produktif (Cash Waqf) Dalam Perspektif Hukum Islam Dan Maqāṣid Al-Sharī'Ah,” Walisongo: Jurnal Penelitian Sosial Keagamaan 24, no. 1 (June 15, 2016): 17, https://doi.org/10.21580/ws.24.1.680.

34 "Baitul Asyi, Anggito, Dan Hikmah Wakaf - Serambi Indonesia," accessed September 18, 2020, https://aceh.tribunnews.com/2018/03/11/baitul-asyi-anggito-dan-hikmah-wakaf.

35 “4.688 Jemaah Haji Aceh Terima Dana Wakaf Rp 4,5 Juta per Orang - Haji Liputan6.Com," accessed September 18, 2020, https://www.liputan6.com/haji/read/4024717/4688-jemaah-hajiaceh-terima-dana-wakaf-rp-45-juta-per-orang.

${ }^{36}$ Aam Slamet Rusydiana and Salman Al Farisi, "How Far Has Our Wakaf Been Researched?," ETIKONOMI 15, no. 1 (April 3, 2016): 31-42, https://doi.org/10.15408/etk.v15i1.3110.
} 
Pada kebanyakan masyarakat Indonesia tradisionalis yang notabennya menganut mazhab Syāfi'i, memahami bahwa harta wakaf itu harus benda yang kekal manfaatnya sehingga tidak boleh wakaf barang yang tidak kekal, seperti uang, makanan, munuman dan lainnya. Hal ini dapat kita lihat dalam makna wakaf yang diuraikan oleh Imam Syāfi'i dan berbeda dengan apa yang dikemukakan oleh Hanafi. Menurut Imam Syāfi'i bahwa wakaf adalah ;3 $^{37}$

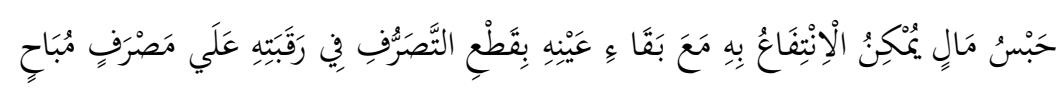

Sedangkan Imam Hanafi memberikan penjelasan bahwa wakaf adalah;

$$
\text { حَبْسُ العين على الحكم ملك الواقف و التصدق بالمنفعة على جهة الخير }
$$

Letak perbedaannya yaitu Imam Syāfi'i menjelaskan bahwa ketentuan benda dan manfaat benda tersebut tidak menjadi milik wākif lagi sedangkan Imam Hanafi yang diwakafkan hanyalah manfaat dari barang tersebut sedangkan barang tersebut masih milik wākif. Jadi kebanyakan masyarakat aceh lebih memilih wakaf tanah yang dianggap kekal dan dianggap lebih manfaat bagi sebagian masyarakat Indonesia sebagaimana pendapat dari Imam Syāfi'i. Oleh karena itu, aset wakaf kebanyakan berupa tanah, seperti tanah sawah, kebun, pekarangan, pertapakan toko, tambak dan sebagainya, sebagian dari tanah tersebut juga di manfaatkan untuk mendirikan masjid, meunasah, balai pengajian, dayah, dan pemakaman umum, hingga saat ini pengelolaan wakaf di Indonesia hanya fakus untuk kegiatan keagamaan saja, belum secara menyeluruh mencapai tahap produktif.

\section{Penutup}

Berdasarkan penelusuran hadis tentang wakaf menunjukan bahwa pesyariatan wakaf sudah dimulai sejak masa Rasul dan terus berkembang hingga sekarang, hanya saja konsep wakaf pada masa Rasul dipahami sebagai bentuk harta yang bersifat kekal dan tetap, sehingga tujuan dari pengelolaan wakaf merupakan tujuan sosial untuk mensejahterakan masyarakat. Dari beberapa hadis yang terkait tidak ditemukan perbedaan matan hadis, perbedaan terletak pada jalur sanad. Hadis wakaf riwayat Bukhari merupakan dasar hukum wakaf dan hal ini disepakati oleh manyoritas ulama fikih. Meskipun begitu, nyatanya praktik wakaf masih mengalami perdebatan antara kalangan fundamentalis dan kontekstualis yang memberikan pemaknaan yang luas tentang wakaf.

\footnotetext{
${ }^{37}$ Muhammad Musthafa Tshalabi, Al-Ahkam Al-Washaya Wa Al-Auqaf(Mesir: Dār Al-Thaif, tth). 333
} 


\section{D a f t a r}

Abdul Baqī, Muhammad Fuad. Al-Mu'jam Al-Mufahras Li Al-Fādh Al-Quran Al-Karim. Mesir: Dar Al-hadist, 2001.

Abi Bakr, Taqiyuddin. Kifayah al Akhyar. 1st ed. Mesir: Dar al-Kitab al-Araby, tth.

A.J. Wensinck, J.P. Mensing, and Brugman J. Al- Mu'jam al-Mufahras Li alFadhi al-Hadis al-Nabawi. 1st ed. Leiden: E.J. Brill, 1969.

Al-Asqalani, Ibnu Hajar. Fathu Al-Bari. 5th ed. Beirut: Dār al-Fikr, 2000.

—. Tahdzib Al-Tahdzib. 4th ed. Beirut: Dār al-Fikr, 1995.

—. Tahdzib Al-Tahdzib. 8th ed. Beirut: Dār al-Fikr, 1995.

Andariati, Leni. "Hadis dan Sejarah Perkembangannya." Diroyah: Jurnal Studi Ilmu Hadis 4, no. 2 (April 13, 2020): 154-66. https://doi.org/10.15575/diroyah.v4i2.4680.

Anwar, Latifah. "Hadis Dan Sunnah Nabi Dalam Perspektif Joseph Schacht." Al-Bayan: Jurnal Ilmu al-Qur'an dan Hadist 3, no. 2 (July 26, 2020): 174-94. https://doi.org/10.35132/albayan.v4i2.91.

_- "Penulisan Hadis Pada Masa Rasulullah SAW." Al-Bayan: Jurnal Ilmu al-Qur'an dan Hadist 3, no. 2 (July 19, 2020): 131-56. https://doi.org/10.35132/albayan.v4i2.88.

Asqalani, Ibn Hajar al-. Fathul Al-Bari Syarh Shahih al-Bukhari. 5th ed. Riyadh: Maktabah al-Malik Fahd al-Wathaniyah, 2001.

Athar, Shidqi Hamil al-’. "Sunan Abi Dawud," 39. Beirut: Dār al-Fikr, 2003.

"Baitul Asyi, Anggito, Dan Hikmah Wakaf - Serambi Indonesia." Accessed September 18 2020. https://aceh.tribunnews.com/2018/03/11/baitul-asyi-anggito-danhikmah-wakaf.

Bukhari, Muhammad Ibn al-. Shahih Al-Bukhāri. 3rd ed. Beirut: Dār al-Fikr, 1981. 
Dahlan, Rahmat. "Análisis Kelembagaan Badan Wakaf Indonesia.” ESENSI 6, no. 1 (May 17, 2016): 113-24. https://doi.org/10.15408/ess.v6i1.3125.

Direktorat Pemberdayaan Wakaf Departemen Agama RI. Fiqih Wakaf. Jakarta: : Direktorat Pemberdayaan Wakaf Departemen Agama RU, 2006.

Fauza, Nilna. "Rekonstruksi Pengelolaan Wakaf: Belajar Pengelolaan Wakaf Dari Bangladesh dan Malaysia." UNIVERSUM 9, no. 2 (July 1, 2015): 161-71. https://doi.org/10.30762/universum.v9i2.83.

Hajjaj, Muslim bin. Shahih Muslim. Beirut: Dār Al-Kutub Al-'Ilmiyah, tth.

Ikromi, Zul. "Fiqh al-Hadits:" Al-Bukhari : Jurnal Ilmu Hadis 3, no. 1 (June 24, 2020): 105-29. https://doi.org/10.32505/al-bukhari.v3i1.1534.

Imam Abi Zakaria bin Syaraf, al-Nawawi al-Syāfi'i. Riyadus Al-Shālihin. Beirut: Dār Al-Kutub Al-Islāmī, 2010.

Isa, Zuraidah Mohamed, Norhidayah Ali, and Rabitah Harun. "A Comparative Study of Waqf Management in Malaysia." IPEDR:International Conference on Sociality and Economics Development 10 (2011): 561-65.

Juliandi, Budi. "Wakaf Dan Politik Di Tunisia." AHKAM : Jurnal Ilmu Syariah 15, no. 2 (July 20, 2015): 137-44. https://doi.org/10.15408/ajis.v15i2.2857.

Khin, Mushtafa al-. Al-Fiqh al-Manhajī 'Alā Mazhab Imām al-Syāfi'i. 5th ed. Beirut: Dār al-Qalam, 1992.

Luthfi, Mukhtar. Optimalisasi Pengelolaan Wakaf. 1st ed. Makasar: Alauddin Press, 2011.

Mughniyah, Muhammad Jawad. Fiqih Lima Mazhab: Ja'fari, Hanafi, Maliki, Syafi'i, Hambali. Shaf, 2015.

Nurudin, Muhammad. "Memahami Hadis Wakaf Dalam Konstalasi Masyarakat global." Junal Zakat dan Wakaf 2, no. 1 (2015): 25.

Rachmat, Nashiruddin. Harta Wakaf: Pengertian, Perkembangan Dan Sejarahnya Didalam Masyarakat Islam Dulu Dan Sekaran. Jakarta: Bulan Bintang, 1964. 
Rahman, Andi. "Pengenalan Atas Takhrij Hadis." Riwayah: Jurnal Studi Hadis 2, no. 1 (March 29, 2017): 146. https://doi.org/10.21043/riwayah.v2i1.1617.

Rusyd, Ibn. Bidāyah Al-Mujtahid Wa Nihāyah al-Muqtashid. Vol. 2. Mesir: Mathba'ah al-Babiy al-Halabiy, 1960.

Rusydiana, Aam Slamet, and Salman Al Farisi. "How Far Has Our Wakaf Been Researched?" ETIKONOMI 15, no. 1 (April 3, 2016): 31-42. https://doi.org/10.15408/etk.v15i1.3110.

Sabiq, Sayyid. Fiqh Al-Sunnah. Vol. III. Mesir: Dâr al-Fath Li 'Ilmi al-'Arabi, 1997.

Sumbulah, Umi. Kritik Hadits, Pendekatan Historis Metodologis. Malang: UIN Malang Press, 2008.

Suryadi, Mr. "Rekonstruksi Kritik Sanad Dan Matan Dalam Studi Hadis." ESENSIA: Jurnal Ilmu-Ilmu Ushuluddin 16, no. 2 (October 1, 2015): 177. https://doi.org/10.14421/esensia.v16i2.996.

Suryani, Suryani, and Yunal Isra. "Wakaf Produktif (Cash Waqf) Dalam Perspektif Hukum Islam Dan Maqāșid Al-Sharī'Ah." Walisongo: Jurnal Penelitian Sosial Keagamaan 24, no. 1 (June 15, 2016): 17. https://doi.org/10.21580/ws.24.1.680.

Tshalabi, Muhammad Musthafa. Al-Ahkam Al-Washaya Wa Al-Auqaf. Mesir: Dār Al-Thaif, tth.

Usman, Nurodin. "Studi Hadis-Hadis Wakaf Dalam Kitab Sahih Al-Bukhari Dan Fath Al-Bari." CAKRAWALA 10, no. 2 (2015): 19.

Zubaidah. "Metode Kritik Sanad Dan Matan Hadits." Jurnal Komunikasi Dan Pendidikan Islam 4, no. 1 (June 2015): 43-80.

Zuhaili, Wahbah. Al-Fiqhu al-Islamī Wa 'Adillatuhu. 6th ed. Damaskus: Dār al-Fikr al-Mu'āshir, 2008.

“4.688 Jemaah Haji Aceh Terima Dana Wakaf Rp 4,5 Juta per Orang - Haji Liputan6.Com." Accessed September 18, 2020. https://www.liputan6.com/haji/read/4024717/4688-jemaah-hajiaceh-terima-dana-wakaf-rp-45-juta-per-orang. 